\title{
Isolasi dan identifikasi bakteri asam laktat hasil fermentasi kol merah \\ (Brassica oleracea L.) sebagai probiotik potensial \\ (Isolation and identification lactic acid bacteria from red cabbage (Brassica oleracea L.) fermentation as potential probiotic)
}

\author{
Grisella Rambitan ${ }^{1)}$, Johanis J Pelealu ${ }^{1)}$, Trina E Tallei ${ }^{\left.1^{*}\right)}$ \\ 1) Program Studi Biologi, Fakultas MIPA, Universitas Sam Ratulangi \\ Jl. Kampus UNSRAT FMIPA, Manado 95115 \\ *)Email korespondensi: trina_tallei@unsrat.ac.id
}

Diterima 28 Juni 2018, diterima untuk dipublikasi 1 Agustus 2018

\begin{abstract}
Abstrak
Bakteri asam laktat merupakan kelompok bakteri yang menghasilkan asam laktat sebagai produk utama dalam fermentasi. Bakteri ini sering disebut probiotik sebab memberikan dampak positif bagi tubuh manusia. Setiap spesies bakteri asam laktat memiliki efek probiotik yang berbeda-beda sehingga diperlukan seleksi dan identifikasi untuk mendapatkan strain probiotik yang baik. Identifikasi bakteri asam laktat dalam penelitian ini menggunakan metode identifikasi molekuler dengan gen penanda $16 S$ rRNA. Bakteri asam laktat dari fermentasi kol merah memiliki kemiripan 100\% dengan Weissella cibaria dan Weissella confusa. Analisis filogenetik menunjukkan hubungan kekerabatan antara isolat bakteri asam laktat dari fermentasi kol merah dengan bakteri genus Weissella yang lain.

Kata kunci: bakteri asam laktat, fermentasi, 16S rRNA, probiotik
\end{abstract}

\section{Abstract}

Lactic acid bacteria is a group of bacteria that produce lactic acid as the main product in fermentation. These bacteria are often called probiotics because can confer a positive impact on the human body. Each species of lactic acid bacteria has a different probiotic effect that requires selection and identification to obtain a good probiotic strain. The identification of lactic acid bacteria in this study used a method of molecular identification with a marker gene of $16 S$ rRNA. Lactic acid bacteria from red cabbage fermentation have a 100\% similarity to Weissella cibaria and Weissella confusa. Phylogenetic analysis showed a relationship between lactic acid bacteria isolates from red cabbage fermentation with bacteria from the other Weissella genus.

Keywords: lactic acid bacteria, fermentation, $16 S$ rRNA, probiotics

\section{PENDAHULUAN}

Bakteri Asam Laktat (BAL) merupakan kelompok bakteri yang menghasilkan asam laktat sebagai produk utama dalam fermentasi (Masood et al. 2011). Bakteri asam laktat banyak ditemukan pada produk makanan olahan yang difermentasi (Nudyanto dan Zubaidah 2015) dan dapat memberikan dampak yang positif bagi kesehatan (Nuraida 2015).
Bakteri Asam Laktat membentuk asam laktat, sebagai produk utama dalam metabolisme karbohidrat (Nudyanto dan Zubaidah 2015). Bakteri-bakteri ini tergolong dalam Gram positif, tidak membentuk spora, berbentuk coccus atau basil dan pada umumnya bersifat katalase negatif (Nudyanto dan Zubaidah 2015), menghasilkan asam laktat sebagai produk akhir dari fermentasi karbohidrat (Pundir et 
al. 2013). Golongan bakteri asam laktat ini dapat tumbuh dengan atau tanpa oksigen (Ray and Montet 2014).

BAL memiliki kemampuan
untuk mencegah dan
menyembuhkan berbagai penyakit sehingga menjadikan bakteri ini digolongkan sebagai salah satu probiotik (Saranraj et al. 2013). Banyak penelitian telah dilakukan untuk mengeksplorasi BAL dari makanan fermentasi lainnya sebagai probiotik potensial (Nuraida 2015). Setiap spesies maupun strain BAL memiliki efek probiotik yang berbeda-beda (Lei 2006). Seleksi bakteri asam laktat diperlukan untuk mendapatkan strain probiotik yang unggul karena tidak semua BAL merupakan probiotik potensial (Fuller 1989 dalam Tambunan 2016). Probiotik potensial yaitu probiotik yang memilik sifat positif misalnya menghasilkan senyawa antibakteri (Belicová et al. 2013) maupun antikolesterol (Guo et al. 2010). Penelitian ini bertujuan untuk mengidentifikasi bakteri asam laktat dari fermentasi kol merah.

\section{METODE}

Fermentasi

Fermentasi kol merah menggunakan larutan garam 15\% pada suhu ruang selama 7 hari di dalam Mason jar yang ditutup rapat.

\section{Isolasi bakteri}

Cairan hasil fermentasi dipindahkan ke media MRS ( de Man, Rogosa and Sharpe) agar untuk melihat pertumbuhan bakteri asam laktat. Selanjutnya diinkubasi selama 48 jam dengan suhu $37^{\circ} \mathrm{C}$ (Lawalata et al. 2011). Setelah bakteri tumbuh, masing-masing koloni yang di sekitarnya berwarna bening dimurnikan pada MRS agar yang baru dengan metode streak plate.

\section{Ekstraksi DNA dan amplifikasi gen 16S rRNA}

Ekstraksi DNA bakteri asam laktat dilakukan menggunakan Plant Genomic DNA mini kit Geneaid GP100. Amplifikasi gen 16S rRNA menggunkan kit My Taq HS Red Mix (Bioline). Primer yang digunakan yaitu BKXF (forward) dan BKXR (reverse) dengan konsentrasi masing-masing $10 \mu \mathrm{M}$ (Kolondam 2018 komunikasi pribadi). Sebelum memulai proses amplifikasi terlebih dahulu membuat Mastermix dengan komposisi MyTaq $20 \mu \mathrm{l}$, DNA $2 \mu \mathrm{l}$, primer forward dan reverse masing-masing 1,5 $\mu \mathrm{l}$ dan MilliQ water $15 \mu$ l sehingga total reaksinya sebesar $40 \mu \mathrm{l}$. Pengaturan suhu untuk PCR diatur sebagai berikut: denaturasi awal pada $95^{\circ} \mathrm{C}$ selama 3 menit, kemudian dilanjutkan dengan denaturasi pada suhu $95^{\circ} \mathrm{C}$ selama 30 detik, penempelan primer pada suhu $50^{\circ} \mathrm{C}$ selama 30 detik, elongasi pada suhu $72^{\circ} \mathrm{C}$ selama 90 detik dan dilakukan sebanyak 35 siklus. Tahap terakhir yaitu polimerisasi pada suhu $72^{\circ} \mathrm{C}$ selama 1 menit. Fragmen DNA yang telah diamplifikasi beserta dengan primer dikirim ke First Base C.O Malaysia untuk di sekuensing.

\section{Analisis Data}

Analisis data hasil sekuensing dianalisis dengan menggunakan prosedur yang dibuat oleh Tallei dan Kolondam (2015). DNA hasil sekuensing disunting menggunakan Geneious v 5,6. Sekuens yang tidak dapat dibaca pada bagian awal dan akhir dihilangkan. Untuk memadukan hasil sekuensing yang menggunakan primer reverse dan primer forward maka dilakukan pairwise alignment. Sekuens DNA dianalisis menggunakan Basic Local Alignment Search Tool (BLAST) (http://blast.ncbi.nlm.nih.gov/Blast.cg i) untuk mencari sekuens yang serupa yang tersedia di GenBank. Sekuens 16S rRNA dijajarkan menggunakan Multalin v.5.4.1 
(multalin.toulouse.inra.fr/multalin/). Setelah itu, pohon filogenetik dibuat menggunakan piranti MEGA6 dengan metode UPGMA. Jarak genetik diperoleh berdasarkan Kimura-2 parameter method yang terintegrasi pada MEGA6.

\section{HASIL DAN PEMBAHASAN}

Fermentasi dilakukan selama 7 hari untuk mendapatkan bakteri asam laktat yang mampu bertahan dalam kadar garam yang tinggi. Cairan hasil fermentasi kemudian ditumbuhkan pada media MRS agar. Pada hari yang kedua dapat diamati koloni-koloni dari bakteri asam laktat. Dari hasil pemurnian, diamati dari morfologi koloni bakteri ada dua isolat dengan morfologi koloni yang berbeda yang diberi nama GR1 (Gambar 1a) dan GR2 (Gambar 1b).

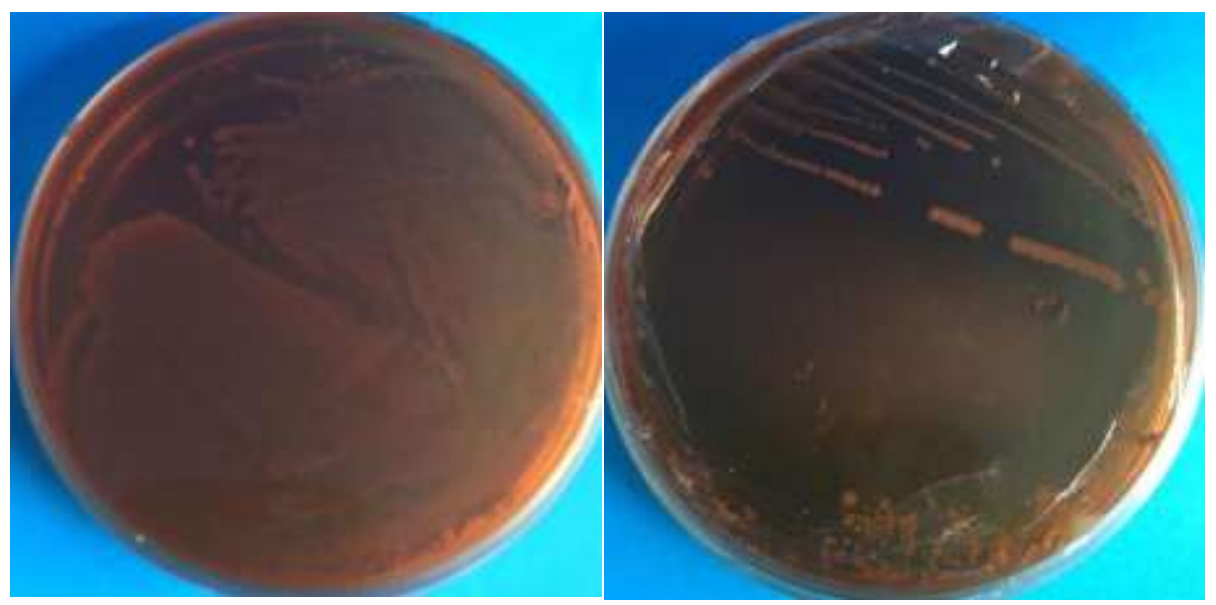

(a)

(b)

Gambar 1. Hasil pemurnian bakteri, (a) isolat GR1 dan (b) isolat GR2

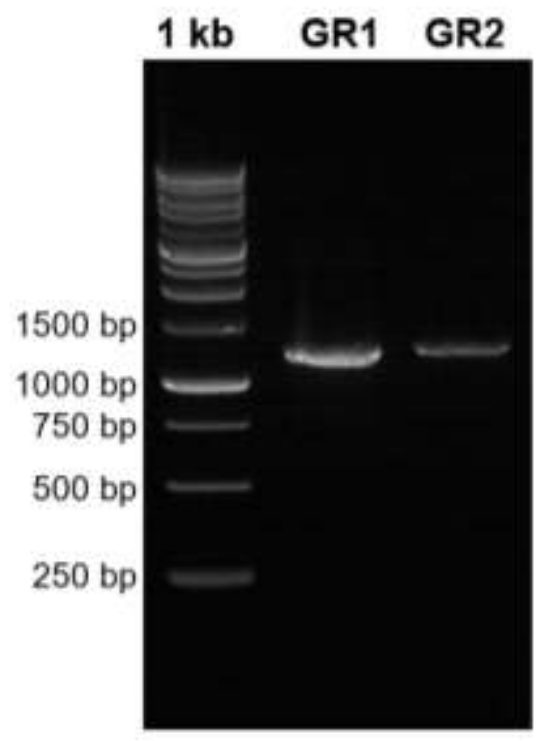

Gambar 2. Visualisasi hasil amplifikasi fragmen gen 16S rRNA dari sampel GR1 dan GR2 


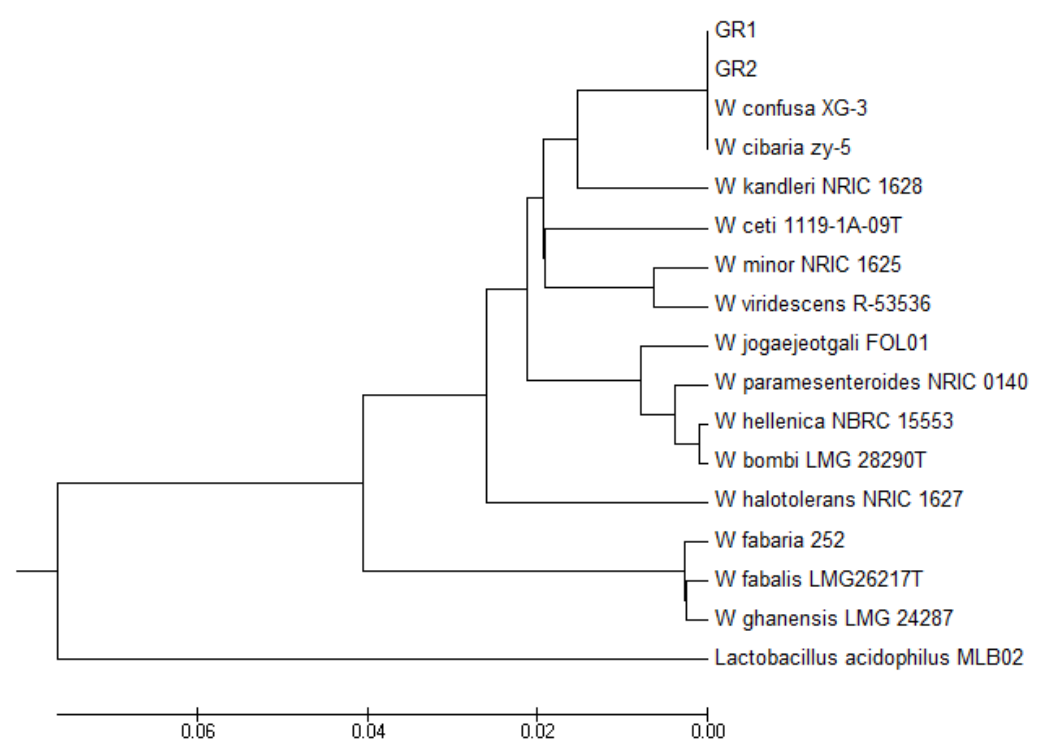

Gambar 3. Pohon filogenetik Weissella yang dikonstruksi menggunakan metode UPGMA

\section{Identifikasi Bakteri Asam Laktat menggunakan Gen Penanda 16S rRNA}

Berdasarkan hasil elektroforesis fragmen DNA bakteri yang telah diamplifikasi (Gambar 2) dapat diketahui bahwa panjang fragmen DNA berada pada kisaran 1000-1500 bp. Dengan meggunakan metode BLAST search, dicari beberapa sekuens yang mempunyai kemiripan dengan sekuens GR1 dan GR2. Dari hasil pencarian diketahui GR1 dan GR2 mempunyai kemiripan 100\% dengan Weissella cibaria dan Weissella confusa. Menurut hasil penelitian sekuens 16S rDNA yang dilakukan oleh Björkroth et al. (2002), W. confusa memiliki kemiripan $99,2 \%$ dengan W. cibaria. Kemiripan 100\% GR1 dan GR2 baik dengan $W$. cibaria maupun $W$. confusa kemungkinan disebabkan oleh perbedaan primer yang digunakan dalam penelitian ini dengan yang digunakan oleh Björkroth et al. (2002). Weissella cibaria dapat ditemukan pada hasil fermentasi kimchi Korea (Kang et al. 2016). W. cibaria, W. koreensis dan W. confusa dilaporkan mendominasi pada tahap awal fermentasi kimchi.

\section{Analisis Filogenetik}

Hasil penjajaran dan konstruksi pohon filogenetik (Gambar 3) memperlihatkan posisi GR1 dan GR2 berada satu cluster dengan $W$. cibaria dan $W$. confusa. Berdasarkan pohon filogenetik juga dapat dilihat bahwa GR1 dan GR2 berkerabat dekat dengan $W$. kandleri. Lactobacillus acidophilus digunakan sebagai penanda outgroup. Dari hasil filogenetik serta pengukuran jarak genetik yang menunjukan nilai 0,154 dapat dilihat bahwa $L$. acidophilus berkerabat jauh dengan GR1 dan GR2. Hasil pengukuran jarak genetik GR1 dan $W$. confusa menunjukkan nilai 0,000. Jarak genetik antara GR1 dan $W$. kandleri yaitu 0,030 yang menandakan hubungan kekerabatan yang cukup dekat. Hubungan kekerabatan dari tiap spesies dapat diukur dari besar kecilnya jarak genetik. Semakin sedikit nilai jarak genetik antara dua organisme, semakin dekat pula hubungan kekerabatan keduanya (Tallei et al. 2016).

\section{KESIMPULAN}

Bakteri asam laktat yang diisolasi dari fermentasi kol merah 
memiliki kemiripan 100\% dengan Weissella cibaria dan Weissella confusa.

\section{DAFTAR PUSTAKA}

Belicová $A$, Mikulášová $M$, Dušinský $R$ (2013) Probiotic potential and safety properties of Lactobacillus plantarum from Slovak Bryndza Cheese. BioMed Res. Int. Volume 2013

Björkroth KJ, Schillinger U, Geisen R, Weiss N, Hoste B, Holzapfel WH, Korkeala HJ, Vandamme $\mathrm{P}$ (2002) Taxonomic study of Weissella confusa and description of Weissella cibaria sp. nov., detected in food and clinical samples. Int. J. Syst. Evol. Microb 52:141-148

Guo LD, Yang LJ, Huo GC (2011) Cholesterol removal by Lactobacillus planarum isolated from homemade fermented cream in inner Mongolia of China. Czech J. Food Sci 29(3): 219-225

Kang BK, Cho MS, Park DS (2016) Red pepper powder is a crucial factor that influences the ontogeny of Weissella cibaria during kimchi fermentation. Scientific Reports 6:28232

Lawalata HJ, Sembiring L, Rahayu ES (2011) Molecular identification of lactic acid bacteria producing antimicrobial agents from bakasang, an Indonesian traditional fermented fish product. Indonesian Journal of Biotechnology 16(2): 93-99

Lei V (2006) Probiotic potential of African fermented millet. Thesis. Department of Food Science, University of Copenhagen

Masood MI, Qadir MI, Shirazi JH, Khan IU (2011) Beneficial effects of lactic acid bacteria on human beings. Critical Reviews in Microbiology 37(1): 1-98

Nudyanto A, Zubaidah E (2015) Isolasi bakteri asam laktat penghasil eksopolisakarida dari kimchi. Jurnal Pangan dan Agroindustri 3(2): 743-748

Nuraida L (2015) A review: health promoting lactic acid bacteria in traditional Indonesian fermented foods. food science and human wellness 4: 47-55

Pundir RK, Rana S, Kashyap N, Kaur (2013) A probiotic potential of lactic acid bacteria isolated from food samples: an in vitro study. Journal of Applied Pharmaceutical Science 3(03): 085-093

Ray R, Montet D (2014) Microorganisms and fermentation of traditional foods. Boca Raton: CRC Press.

Saranraj $P$, Naidu MA, Sivasakthivelan P (2013) Lactic acid bacteria and its antimicrobial properties: a review. International Journal of Pharmaceutical \& Biological Archives 4(6): $1124-1133$

Tallei TE, Kolondam BJ (2015) DNA barcoding of Sangihe Nutmeg (Myristica fragrans) using matK gene. Hayati Journal of Biosciences 22(1):41-47

Tallei TE, Rembet RE, Pelealu JJ, Kolondam BJ (2016) Sequence variation and phylogenetic analysis of Sansevieria trifasciata (Asparagaceae). Bioscience Research 13(1): 01-07

Tambunan AR (2016) Karakteristik probiotik berbagai jenis bakteri asam laktat (BAL) pada minuman fermentasi laktat sari buah nanas. Skripsi. Fakultas Pertanian Universitas Lampung, Bandar Lampung 